\title{
EFEKTIVITAS KURIKULUM TINGKAT SATUAN PENDIDIKAN DALAM PEMBELAJARAN SENI MUSIK PADA SMP NEGERI 4 AMBON MALUKU
}

\author{
Chrisema Ramayona Latuheru \\ Pascasarjana Institut Seni Indonesia, Yogyakarta \\ e-mail : zzttnarayana1993@gmail.com \\ Diterima : 10 Maret 2019. Disetujui : 9 Mei 2019. Dipublikasikan : 30 Juni 2019 \\ (C)2019 - DESKOVI Universitas Maarif Hasyim Latif. Ini adalah artikel dengan akses \\ terbuka di bawah lisensi CC BY 4.0 (https://creativecommons.org/licenses/by/4.0/)
}

\begin{abstract}
ABSTRAK
Kurikulum di Indonesia dinilai terlalu kompleks dibandingkan dengan kurikulum yang ada di beberapa negara maju sehingga beban siswa dalam belajar semakin berat. Atas dasar inilah diperlukan KTSP, kurikulum operasional yang dikembangkan dan dilaksankan oleh sekolah. SMP Negeri 4 Ambon merupakan sekolah yang mengembangkan kurikulum sesuai dengan karakteristik dan kebutuhan sekolah. Permasalahan yang akan dibahas dalam penelitian ini adalah, apa saja kendala dalam pelaksanaan KTSP di SMP Negeri 4 Ambon, bagaimana upaya guru dalam menyelesaikan masalah dalam pelaksanaan KTSP, dan bagaimana upaya guru dalam menyumbangkan pikirannya dalam pelaksanaan pembelajaran musik. Penelitian ini juga dilandasi dengan beberapa teori-teori terdahulu yang telah meneliti efesiensi pembelajaran musik. Proses penelitian ini menggunakan metode penelitian kualitatif dengan pendekatan studi kasus dan FGD (Focus Group Discussion) yang diperoleh dari wawancara terbuka dan diskusi terpadu. Hasil penelitian menunjukkan, kendala yang ditemui dalam penerapan KTSP pada pembelajaran seni musik antara lain, kendala siswa dalam mengaransir lagu, guru masih menggunakan ruangan kelas umum pada saat praktek, alat musik yang digunakan belum memadai, alokasi waktu yang masih kurang dan kurangnya tenaga guru. Dalam penerapan KTSP guru berusaha mengatasi kendala-kendala tersebut dengan menyumbangkan pemikirannya melalui solusi-solusi yang diterapkannya, antara lain dengan memudahkan anak mengaransir lagu, melalui lagu sederhana yang diaransirnya dan memanfaatkan waktu diluar jam sekolah untuk menyelesaikan materi yang tertunda.
\end{abstract}

Kata kunci: Efektivitas, KTSP, Guru musik, pembelajaran musik

\begin{abstract}
The curriculum in Indonesia is considered too complex compared to other countries so that students in learning is getting harder. On this basis KTSP is needed, an operational curriculum developed and implemented by the school. SMP Negeri 4 Ambon is a school that develops a curriculum in accordance with the characteristics and needs of the school. The problems to be discussed in this study are, what are the obstacles in the implementation of KTSP in SMP Negeri 4 Ambon, how are the efforts of the teacher in solving problems in the implementation of KTSP, and how the teacher attempts to contribute his thoughts in the implementation of music learning. This research is also based on several previous theories that have examined the efficiency of music learning. The process of this research uses qualitative research methods with a case study approach and FGD (Focus Group Discussion) obtained from open interviews and integrated discussions. The results showed that the obstacles encountered in the application of KTSP in the learning of musical arts included the constraints of students in arranging songs, teachers still using public classrooms at the time of practice, inadequate musical instruments, lack of time allocation and lack of teachers. In applying the KTSP the teacher tries to overcome these obstacles by contributing his thoughts through the solutions he applies, among others by making it easier for children to organize songs, through simple songs arranged and utilizing time outside of school hours to complete the delayed material.
\end{abstract}

Keyword: Effectiveness, KTSP, Music teacher, Music learning

\section{PENDAHULUAN}

Negara Indonesia merupakan salah satu negara berkembang yang perlu adanya proses untuk lebih maju, yaitu dengan mencerdaskan anak bangsa. Pendidikan yang bermutu dan berkualitas dapat meningkatkan kecerdasan anak bangsa dalam menghadapi dampak global, ketika Ipteks sangat berperan penting sebagai landasan yang kuat dalam melakukan proses pendidikan. Kurikulum yang ada di Indonesia dinilai terlalu kompleks dibandingkan dengan kurikulum yang diterapkan di beberapa negara 
maju sehingga beban siswa dalam belajar semakin berat. Pendidikan mempunyai peranan sangat penting dalam keseluruhan aspek kehidupan manusia. Hal itu disebabkan pendidikan berpengaruh langsung terhadap perkembangan manusia, perkembangan seluruh aspek kepribadian manusia. Kurikulum sebagai sebuah rancangan pendidikan mempunyai kedudukan yang sangat strategis dalam seluruh aspek kegiatan pendidikan. Dalam konteks ini dapat dikatakan bahwa kurikulum yang baik semestinya akan menghasilkan proses dan produk pendidikan yang baik. Mengingat pentingnya peranan kurikulum dalam pendidikan maka penyusunan kurikulum tidak dapat dilakukan tanpa landasan yang kokoh. Oleh sebab itu dalam mengembangkan kurikulum, terlebih dahulu harus diindentifikasi secara akurat, selektif, mendalam dan menyeluruh landasan apa saja yang harus dijadikan pijakan dalam merancang dan mengembangkan kurikulum.

Landasan pengembangan kurikulum yang diterapkan oleh Pemerintah (Depdikbud) antara lain adalah landasan filosofis, psikologis, sosiologis, serta landasan ilmu pengetahuan dan teknologi dan seni (ipteks). Adapun yang dimaksud dengan landasan filosofis dalam pengembangan kurikulum adalah asumsi-asumsi atau rumusan yang didapat dari hasil berpikir secara mendalam, analitis, logis, dan sistimatis dalam merencanakan, melaksanakan, dan mengembangkan kurikulum untuk penggunaannya baik dalam bentuk program (tertulis) maupun dalam pelaksanaan (operasional) di sekolah. Landasan psikologis pengembangan kurikulum yang didalamnya kurikulum sebagai program atau alat untuk merubah perilaku peserta didik (siswa) ke arah yang diharapkan oleh pendidikan, maka tentu saja dalam mengembangankan kurikulum pendidikan harus menggunakan asumsi-asumsi atau landasan yang bersumber dari ilmu psikologi. Dan pada dasarnya ada dua jenis psikologi dalam mengembangkan kurikulum antara lain, psikologi perkembangan dan psikologi belajar. Psikologi perkembangan adalah ilmu yang mengkaji perkembangan manusia, sedangkan psikologi belajar adalah suatu pendekatan atau studi yang mengkaji bagaimana manusia umumnya melakukan proses belajar. Pada landasan Sosiologis, ilmu pengetahuan, teknologi dan seni, pendidikan adalah proses budaya artinya manusia yang akan di didik adalah mahkluk yang berbudaya dan senantiasa mengembangkan kebudayaannya. Oleh sebab itu, kurikulum harus dikembangkan dengan norma-norma sosial, budaya dan seni. Dengan demikian maka pendidikan akan menjadi pewaris budaya dan sekaligus berfungsi untuk mengembangkan kehidupan sosial, budaya dan seni yang lebih baik sesuai dengan perkembangan dan tuntutan masyarakat. Di lain pihak agar kurikulum dapat bertahan kuat, maka pengembangannya harus didasarkan oleh ilmu pengetahuan dan teknologi. Dengan demikian kurikulum akan mampu menyesuaikan dengan situasi dan kondisi yang berkembang.
Sejak tahun 1945 kurikulum di Indonesia selalu mengalami perubahan mulai dari tahun 1947, 1952, 1964, 1968, 1975, 1984, 1994, 2004 dan 2006 yang sedang diterapkan yaitu KTSP (Kurikulum Tingkat Satuan Pendidikan). Kurikulum Tingkat Satuan Pendidikan (KTSP) merupakan model kurikulum yang dikeluarkan oleh pemerintah sebagai penyempurnaan Kurikulum Berbasis Kompetensi (KBK). Kurikulum yang dibuat oleh pemerintah (Depdiknas) adalah kurikulum standar yang berlaku secara nasional. Standar nasional pendidikan terdiri atas standar isi (SI), proses kompetensi kelulusan (SKL), tenaga pendidikan, sarana dan prasaran, pengelolaan, pembiayaan dan penilaian pendidikan. (Dekdikbud 2006). Padahal kondisi sekolah pada umumnya sangat beragam. Oleh karena itu, dalam implementasinya, sekolah dapat mengembangkan (memperdalam, memperkaya, memodifikasi), na mun tidak boleh mengurangi isi kurikulum yang berlaku secara nasional. Selain itu, sekolah diberi kebebasan untuk mengembangkan kurikulum yang ada. Atas dasar inilah diperlukan Kurikulum Tingkat Satuan Pendidikan (KTSP) sebagai kurikulum operasional sekolah. Undang-Undang No.20 tahun 2003 bab I pasal 1 point (15), menyatakan, "KTSP adalah kurikulum operasional yang disusun oleh pemerintah dan dilaksanakan di masing-masing satuan pendidikan." Jadi, dalam KTSP sekolah diberikan kebebasan dalam mengembangkan kurikulum sesuai dengan kareakteristik dan kebutuhan sekolah. Dalam Panduan Penyusunan Kurikulum Tingkat Satuan Pendidikan Jenjang Pendidikan Dasar dan Menengah yang dikeluarkan oleh Badan Standar Nasional pendidikam Nasional menyatakan bahwa KTSP terdiri dari tujuan pendidikan tingkat satuan pendidikan, struktur dan muatan kurikulum tingkat satuan pendidikan, kalender pendidikan, dan silabus.

Silabus merupakan penjabaran standar kompetensi dan kompetensi dasar ke dalam materi pokok, kegiatan pembelajaran, dan indikator pencapaian kompetensi untuk penilaian. Dalam implementasinya silabus dijabarkan dalam Rencana Pelaksanaan Pembelajaran (RPP) dan ditindak lanjuti oleh masing-masing guru. Tetapi dalam pelaksanaanya pun terdapat masalah dan hambatan di antaranya terjadi ketika para guru merumuskan RPP, merumuskan indikator, dan menentukan jenis materi yang relevan yang mendukung tercapainya kompetensi dasar, sehingga sering terjadi kekeliruan dalam menentukan jenis materi yang disajikan. SMP N 4 Ambon, SMP N 4 Ambon terletak di pusat kota Ambon, yang setiap tahunnya sekolah menerima sekitar $70 \%$ peserta didik, dan sekarang sekolah ini memiliki kurang lebih 1.281 peserta didik. Sampai saat ini SMP N 4 Ambon memiliki 69 tenaga pendidik (guru), berstatus PNS dan 46 orang diantaranya telah memiliki sertifikat sebagai tenaga pendidik profesional. Dengan Visi Sekolah "MUTIARAKU" (Manusia unggul, Tertib, Beriman, Berakhlak, Ramah, Kreatif dan Ugahari) dan Misi Sekolah, melaksanakan KTSP, meningkatkan kapasitas 
dan kualifikasi SDM, melaksanakan pembelajaran dengan hasil optimal, melaksanakan kapasitas dan efektivitas sarana dan prasarana pendidikan, menerapkan manajemen berbasis sekolah dan menejemen mutu, meningkatkan sumber dana dan pendanaan pendidikan, mengelola lingkungan sekolah yang menunjuanh kompetetif, dan meningkatkan integrasi pendidikan kecekapan hidup.

Dengan tujuan pendidikan dasar, meletakan dsar kecerdasan, pengetahuan, kepribadian, ahklak mulia serta ketrampilan untuk kehidudpan mandiri dan mengikuti pendidikan lebih lanjut. SMP N 4 Ambon, mengembangkan kurikulum KTSP yang mencakup perkembangan dimensi manusia Indonesia seutuhnya, agar mampu mewujudkan masyarakat, Bangsa dan Negara dalam menghadapi tuntutan perkembangan zaman. Penyusunan KTSP SMP N 4 Ambon bertujuan untuk, pertama sebagai pedoman operasional dalam pelaksanaan dan pengelolaan proses pembelajaran pada SMP N 4 Ambon. Kedua, sebagai acuan dalam merumuskan kebijakan pengembangan kurikulum dimasa depan. Dengan memiliki sarana dan prasarana yang memadai dan didukung oleh tenaga yang profesional yang diharapkan akan mampu menyelenggarakan proses pembelajaran yang aktif, interaktif, kreatif, dan efektif dan menyenangkan sehingga melahirkan lulusan yang berdaya saing tinggi. Dan dari hasil situasi dan konteks yang dimiliki sekolah ini merupakan dasar pijakan untuk menentukan kedalaman dan keluasan target-terget yang ditetapkan. Untuk itu penerapan KTSP tidak dapat jalan berdasarkan data empiris atau data yang dihasilkan dari percobaan atau pengamatan saja.

\section{METODE PENELITIAN}

Metode penelitian berhubungan erat dengan prosedur, teknik, alat serta desain penelitian yang digunakan. Untuk itu memerlukan metodologi yang benar dan yang bisa dipertanggungjawabkan secara ilmiah. Pada bab ini akan diuraikan mengenai masalahmasalah tentang metodologi penelitian yang terdiri dari, subjek penelitian, alat yang digunakan, lokasi penelitian, metode pengumpulan data, jalannya penelitian, dan metode analisis data. Untuk itu sejalan dengan tujuan dan rumusan masalah penelitian, maka metode yang digunakan dalam penelitian ini adalah Metode penelitian kualitatif dengan pendekatan studi kasus (Case Study) dan FGD (Focus Group Discussion).

Pada dasarnya studi kasus mempelajari secara intensif dan rinci sesorang individu atau kelompok yang mengalami kasus tertentu. Data studi kasus dapat diperoleh dengan semua pihak yang bersangkutan, dengan kata lain dalam studi ini dikumpukan dari berbagai sumber. Subjek dapat berupa individu, kelompok, institusi atau masyarakat. Dalam kasus ini, peneliti mempelajari secara khusus dan mendalam dalam kurun waktu sekitar dua bulan lebih. Mendalam artinya, dengan mengungkap semua variabel yang dapat menyebabkan terjadinya kasus tersebut dari berbagai aspek. Peneliti terjun langsung mempelajari suatu proses atau penemuan yang terjadi secara alami, mencatat, menganalisis, menafsirkan, melaporkan, serta menarik kesimpulan dari proses tersebut.

Subjek penelitiannya adalah tiga guru seni budaya dan enam Siswa Sekolah Menengah Pertama antara lain satu orang Guru Seni Musik, satu orang Guru Seni Tari dan satu orang Guru Seni Rupa dari SMP N 4 Ambon, Maluku. Siswa sekolah masingmasingnya dua siswa dari kelas VIII dan empat siswa dari kelas IX. Dimana masing-masing siswa mempunyai ketertarikan dalam pelajaran Seni budaya antara lain Seni Musik, Seni Tari, dan Seni Rupa. Penentuan subjek atau nara sumber penelitian mempertimbangkan prestasi sekolah dalam hal pendidikan musik.

Pengumpulan data dilakukan dengan wawancara dengan Guru Seni Budaya antara lain satu Guru Seni Musik, satu Guru Seni Tari dan satu Guru Seni Rupa dan diskusi terpadu FGD (Focus Group Discussion) dilakukan dengan enam siswa masingmasing kelas VIII dan kelas IX. Wawancara dan diskusi ini dilakukan untuk mengumpulkan data guna menjawab permasalahan yang ada. Wawancara dan diskusi menggunakan tape recorder dengan mengajukan berbagai pertanyaan yang sudah dipersiapkan terlebih dahulu oleh peneliti. Selanjutnya catatan lapangan dan dokumen-dokumen juga menjadi salah satu alat pengumpulan data dalam penelitian ini. Peneliti juga mempelajari Kurikulum SMP N 4 Ambon sebagai petunjuk dan acuan dalam penelitian.

Penelitian dilakukan di SMP Negeri 4 Ambon, Maluku. Terletak di pusat kota Ambon yang adalah ibu Kota Provinsi Maluku, sehingga perkembangannya dari tahun ke tahun selalu disesuaikan dengan kehidupan masyarakat perkotaan. Setiap tahun peserta didik yang masuk sekitar $70 \%$ berasal dari keluarga Pegawai Negeri Sipil (PNS) yang berpenghasilan menengah kebawah tetapi berperilaku selalu ingin maju seiring dengan lajunya perkembangan kehidupan perkotaan. Oleh sebab itu SMP 4 selalu membenah diri dengan berdayakan seluruh potensi dan sumber daya yang ada.

\section{PEMBAHASAN}

Dalam penelitian ini data yang diperoleh diklasifikasikan menjadi dua kelompok, yaitu data dari subjek yang diperoleh dari wawancara dengan Guru Seni Musik, Seni Tari, Seni Rupa dan diskusi dengan enam siswa-siswi dari SMP N 4 Ambon. Masingmasing dari siswa tersebut memiliki ketertarikan dalam pelajaran seni yaitu, dua orang siswa memiliki ketertarikan dalam seni musik, dua orang siswa memiliki ketertarikan dalam pelajaran seni tari dan dua siswa yang memiliki ketertarikan dalam pelajaran seni rupa. Responden yang pertama adalah guru seni budaya yang meliputi guru seni musik, seni tari dan seni rupa. 
Masing-masing mengajar pada jenjang kelas yang berbeda, antara lain Guru seni musik mengajar pada kelas VII dan IX, Guru seni tari mengajar pada kelas VIII sedangkan Guru seni rupa mengajar pada kelas VII dan VIII. Dan ditemukan masing-masing guru ini memiliki kendala dalam penerapannya.

Pada dasarnya dalam perumusan Rencana Pelaksanaan Pembelajaran, indikator dan jenis materi untuk Guru Seni Budaya sudah sesuai dengan peraturan yang berlaku, dalam perumusan RPP yang diawali dengan program tahunan, semester, alokasi waktu, standar kompetensi, kompetensi dasar dan sudah ditentukan minggu efektif dan dapat membagi materi, menyusun silabus didalamnya kompetensi dasar, kegiatan pokok sampai dengan sumber belajar serta ditambahkan Pendidikan karakter. Dalam pendidikan karakter diharapkan siswa dapat disiplin, tekun, tanggung jawab, ketelitian, kerjasama, percaya diri, dan kecintaan.

Namun dalam penerapannya terdapat beberapa faktor kendala. Dalam wawancara dengan Guru Musik (M.L), Ia mengatakan bahwa pengetahuan dasar yang dimiliki anak sangat minim, dikarenakan minimnya tenaga guru seni musik pada Sekolah Dasar.

Dalam proses pembelajaran seni musik, terutama pada saat mengajarkan notasi musik, ditemukan anak lebih dapat membaca dan membunyikan not angka dari pada not balok. Dengan demikian dalam proses belajar notasi, langkah yang ditempuh adalah setelah memperkenalkan bentuk, dan nilai (harga) maka langsung ditransponer ke dalam not angka, baik nama dan nilai notnya disertai bentuk, nama dan nilai tanda diam.

Khusus untuk lagu-lagu mancanegara yang ditulis dengan notasi balok, maka diberikan tugas untuk mentranspornerkan. Selanjutnya untuk mengenalkan tangga nada Krois(\#) dan Mol (b), langkah yang diambil adalah dengan menyederhanakan rumusnya. Contoh :

- Untuk tangga nada Krois (\#) disederhanakan dengan rumus sebagai

berikut: $\mathbf{5}-\mathbf{7}$

Artinya \# : nada yang ke 5 dijadikan nada dasar dan nada yang ke 7 dinaikan $1 / 2$ nada (dikroiskan).

- Untuk tangga nada Mol (b) disederhanakan dengan rumus sebagai

berikut : $\mathbf{4}-\mathbf{4}$

Artinya $\mathrm{b}$ : nada yang ke 4 dijadikan nada dasar dan nada yang ke 4 pula diturunkan $1 / 2$ nada (dimolkan).

Dalam materi ini langsung diajarkan dengan notasi balok $\mathrm{C}-\mathrm{D}-\mathrm{E}-\mathrm{F}-\mathrm{G}-\mathrm{A}-\mathrm{B}-\mathrm{C}$, dan memperkenalkan pola jarak tangga nada diatonis mayor, perlu dijelaskan bahwa materi ini sangat menarik, karena langsung dibunyikan pada alat musik (pianika) dan dibunyikan dari tangga nada $1 \#$ (Krois)1b (Mol), begitu juga pada tangga nada mayor mol. Memang pada penerapannya kedapatan pada tangga nada 6-7\# dan 6-7b, anak-anak menemukan kesulitan, karena pada nada ke 7 untuk nada ke $6 \#$ dan $7 \#$ serta nada yang ke 4 untuk $6 \mathrm{~b}$ dan $7 \mathrm{~b}$, memiliki jarak $1 / 2$, maka dipakailah nada enharmonis (pasangan dua buah nada yang sama bunyi tapi beda nama )F/Eis untuk 6\#, $\mathrm{C} / \mathrm{Bis}$ untuk 7\#, sedangkan untuk Mol (b) Ces/B untuk $6 b$, Fes/E untuk $7 b$.

Untuk mengajarkan siswa mengaransir lagu, langkah awal guru membuat lagu sederhana ciptaannya sendiri, dengan memasukan pola-pola ritmik yang ada dalam lagu mancanegara. Contohnya : Lagu mancanegara yang di pilih "Imagine" dari Johnn Lennon. Pada lagu Gambar. 1 ini diaransir dengan menggunakan Tifa, Tambourin, rebana dan Pianika.

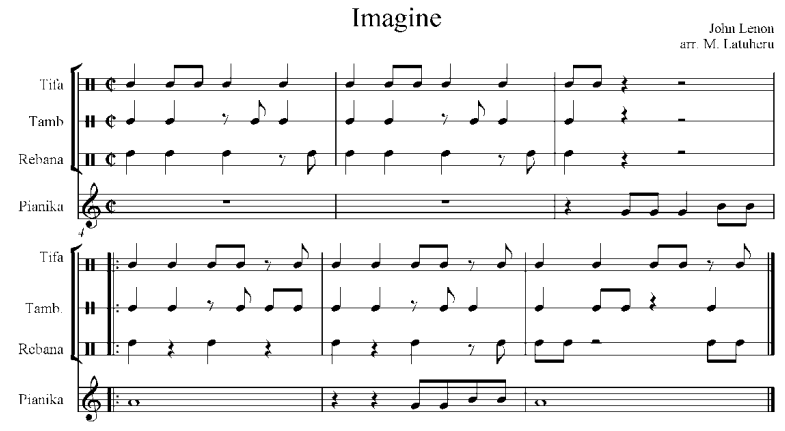

Gambar 1. Penggalan notasi lagu "Imagine" pada birama $1-4$.

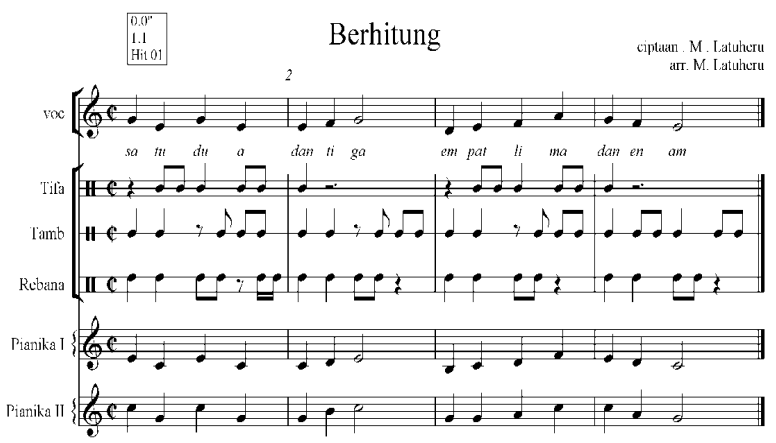

Gambar 2. Penggalan notasi lagu "Berhitung" pada birama $1-4$

Pada lagu Gambar. 2 ini lagu yang diaransir sendiri oleh (M.L), pola-pola ritmik yang ada di dalam lagu mancanegara pada Gambar. 2 dimasukkan pada lagu yang diaransirnya. Dengan memasuk penggalan pola ritmik ini maka siswa lebih mudah, karena sudah diajarkan terlebih dahulu langsung dengan alat -alat musik yang disediakan. Antara lain Tifa, Tambourin, Rebana, Pianika I,II dan III. Selain itu karena keterbatasan waktu untuk ke empat cabang seni maka guru musik mengambil cara untuk penerapan praktek lebih banyak pada jam ekstrakulikuler yang dijadwalkan pada hari Minggu selama 2 jam, dari Pukul 14.00 - 16.00. Dengan kembali menetapkan materi yang diajarkan dikelas, baik itu teori ataupun praktek, walaupun waktu 2 jam pada ektrakulikuler itu lebih diberikan bobot pada praktek. Untuk Guru Seni Tari kendala yang ditemui dalam penerapan KTSP ini adalah kurangnya tenaga guru. Sehingga pada saat penerapan materi untuk tarian mancanegara, guru mendapat kesulitan karena kurangnya referensi, sehingga pada saat praktek guru lebih memilih untuk 
memperlihatkannya lewat pemutaran VCD dll. Dan untuk Guru Seni Rupa, kendala yang ditemui dalam penerapan KTSP yaitu, dalam kurangnya tenaga guru. Sehingga guru lebih cendrung memberikan pelajaran keterampilan (Kerajinan tangan), sehingga dalam proses belajar lebih membutuhkan keaktifan siswa. Misalkan siswa diharapkan dapat membuat suatu benda siap pakai contohnya : tempat tisu, kain penutup meja dan ikat pinggang. Dalam membuat kerajinan tersebut pastinya dibutuhkan bahan, dan sekolah tidak mungkin menyediakan sesuai dengan jumlah siswa.

Sehingga solusi untuk memudahkan siswa yaitu agar bahan-bahan yang digunakan diambil dari alam sekitar dengan memanfaatkan hasil bumi yang ada di Maluku. Salah satunya Buah Cengkih dan Kulibia, dari ide-ide kreatif siswa maka dihasilkan karya ikat pinggang yang terbuat dari buah cengkih yang sudah dikeringkan, serta penutup meja dan tempat tisu yang terbuat dari kulibia.

Responden yang ke dua adalah 6 orang siswa, yang dimana masing-masing mempunyai kesulitan dalam hal alokasi waktu pelajaran, sarana prasarana, jenis materi yang diberikan guru. Ke 6 siswa ini terdiri dari 2 siswa kelas VIII dan dan 4 siswa kelas IX. Dari hasil diskusi dengan siswa, hampir keseluruhan siswa memberi keluhan tentang alokasi waktu, sarana prasarana dan materi pembelajaran. Waktu yang ditentukan dirasa tidak cukup. Misalkan, dalam pelajaran Seni Musik pada kelas IX, siswa mengatakan bahwa pada saat praktek materi yang diberikan adalah siswa diperdengarkan musik atau lagu mancanegara, kemudian siswa diharapkan untuk dapat menentukan asal bunyi yang diperkenalkan, kemudian mengidentifikasi ciri-ciri dan unsur-unsur budaya khas dari musik tersebut, sampai dengan menuliskan keunikan dari musik atau lagu tersebut.

Dirasakan siswa sangat sulit, untuk mendengarkan lagu yang berdurasi sekitar 10-15 menit dan untuk mendengarkan harus membutuhkan kejelian. Dan untuk mengidentifikasi serta menuliskan keunikan lagu tersebut membutuhkan waktu. Alhasil dalam satu kali pertemuan, materi yang diberikan tidak semuanya dapat diterima siswa. Dan akan dilanjutkan kembali pada pertemuan selanjuatnya. Kendala selanjutnya sarana dan prasarana dalam hal ini alat musik, maka pada saat praktek siswa di bagi menjadi beberapa kelompok. Jika dirasakan kelompok pertama sudah mampu memainkan alat musik, maka kelompok pertama akan menjadi tutor sebaya bagi kelompok selanjutnya. Berbeda dengan siswa kelas VIII, yang pada kelas VIII ini tidak diajarkan pelajaran seni musik. Menurut mereka kalau hanya pelajaran musik diberikan pada kelas VII dan kelas IX saja, maka materi yang diberikan pada kelas VII akan sia-sia karena materi yang diberikan pada kelas VII tidak dilanjuti pada kelas VIII, sehingga materi kelas VII akan diajarkan kembali pada kelas IX.

Tabel 1. Matriks Kendala KTSP dalam Materi Pelajaran Seni Budaya pada SMP N 4 Ambon, Maluku.

\begin{tabular}{|c|c|c|}
\hline GURU & KENDALA & SOLUSI \\
\hline $\begin{array}{c}\text { Seni } \\
\text { Musik }\end{array}$ & $\begin{array}{l}\text { 1. Siswa belum mengenal notasi ( nama, } \\
\text { Nilai/harga, bentuk) } \\
\text { 2. Pengenalan nada Krois (\#) dan Mol (b) } \\
\text { 3. Kesulitan siswa dalam mengaransir } \\
\text { Lagu. } \\
\text { 4. Alokasi waktu } \\
\text { 5. Alat musik }\end{array}$ & $\begin{array}{l}\text { 1. Guru memperkenalkan } \\
\text { bagaimana bentuk, nilai, } \\
\text { nama, dan harga pada notasi. } \\
\text { 2. Guru menyederhanakan rumusnya } \\
\text { 3. Guru memberikan materi } \\
\text { dasar untuk pengenalan } \\
\text { unsur musik, yang mengarah } \\
\text { ke mengaransir lagu } \\
\text { mancanegara. } \\
\text { 4. Guru memanfaatkan } \\
\text { kegiatan ektrakulikuler, untuk } \\
\text { memantapkan materi yang } \\
\text { diajarkan di kelas. } \\
\text { 5. Pada saat praktek guru } \\
\text { membuat kelompok, dan } \\
\text { kelompok pertama menjadi } \\
\text { tutor sebaya untuk kelompok } \\
\text { lainnya. }\end{array}$ \\
\hline $\begin{array}{l}\text { Seni } \\
\text { Tari }\end{array}$ & 1. Kurangnya tenaga guru & $\begin{array}{l}\text { 1. Dalam mengajarkan tarian manca } \\
\text { Negara, guru mem }\end{array}$ \\
\hline $\begin{array}{c}\text { Seni } \\
\text { Rupa }\end{array}$ & $\begin{array}{l}\text { 1. Keterbatasan persediaan bahan } \\
\text { yang digunakan dalam keterampilan. } \\
\text { 2. Kurangnya tenaga guru }\end{array}$ & $\begin{array}{l}\text { 1. Guru memanfaatkan hasil } \\
\text { bumi untuk meghasilkan karya } \\
\text { seni. } \\
\text { 1. Dalam pembelajaran guru } \\
\text { lebih cendrung memberikan materi } \\
\text { praktek sesuai kemampuan guru. }\end{array}$ \\
\hline
\end{tabular}


Dalam wawancara dengan siswa kelas IX dan juga merupakan Ketua Osis SMP N 4 Ambon. (M.S) mengatakan bahwa kurang setuju kalau pembelajaran Seni budaya, baik seni musik, seni tari, dan seni rupa tidak diberikan secara merata. Sebaiknya pembelajaran seni budaya diberikan untuk semua jenjang, karena untuk pembelajaran seni musik, jika hanya diberikan pada kelas VII dan kelas IX saja tidak dilanjuti pada kelas VIII, maka dasar yang diberikan pada kelas VII akan sia-sia, biarpun pada nantinya akan dijelaskan lagi pada kelas IX. Untuk itu diharapkan, untuk pembelajaran seni budaya diberikan secara merata.

Hal yang sama juga dirasakan siswa kelas IX pada pelajaran seni tari, dikatakan bahwa satu kali pertemuan dalam praktek, membutuhkan waktu untuk menghafal gerakannya dan belum lagi ketika siswa diharuskan mencontohkannya di depan baik secara individu maupun kelompok. Kemudian ketika siswa diperkenalkan dengan tarian mancanegara. Menurut mereka kalau hanya menonton saja melalui TV atau VCD susah ditangkap. Alangkah baiknya jika ada guru yang mempraktekkan, dan benar-benar guru tersebut mengerti akan tari tarian mancanegara. Sehingga akan lebih mudah untuk siswa pahami baik secara teori maupun prakteknya. Sedangkan untuk siswa kelas VIII dalam pembelajaran seni rupa, siswa lebih banyak diajarkan keterampilan (kerajinan tangan) misalnya; siswa membuat kerajinan tangan berupa penutup meja, ikat pinggang, dan sandal hotel. Dan untuk mereka sendiri, mereka senang dengan materi keterampilan yang dijarkan karena bahan yang digunakan juga mudah didapatkan.

Namun hal ini bertolak belakang dengan pendapat siswa kelas IX, menurut mereka pembelajaran seni rupa bukan hanya yang diajarkan keterampilan saja, tetapi juga harus diajarkan tentang seni patung dan seni lukis. Agar pembelajarannya merata, dan mereka dapat mempelajari hal-hal yang baru. Dalam wawancara dengan siswa kelas IX (V.P) mengatakan bahwa karena siswa tersebut hobby melukis, sebaiknya pembelajaran seni rupa jangan hanya keterampilan dan kerajinan saja yang diberikan. Tapi seni lukis dan patung juga. Biar dapat memotivasi siswa untuk memperdalam bakatnya.

Tabel 2. Rangkuman FGD (Focus Group Discussion)

\begin{tabular}{|c|c|c|c|}
\hline NO & SENI & DIMENSI & RESPONS \\
\hline \multirow[b]{3}{*}{1} & \multirow[b]{3}{*}{ Musik } & Pembelajaran & $\begin{array}{l}\text { - Musik diberikan pada kelas VII, } \\
\text { VIII, dan IX. }\end{array}$ \\
\hline & & Waktu & - Waktu yang ditentukan kurang \\
\hline & & Sarana Prasarana & $\begin{array}{ll}\text { - } & \text { Masih menggunakan ruang } \\
\text { kelas pada saat praktek. } \\
\text { - } \quad \text { Perlu adanya ruangan khusus } \\
\text { Pembelajaran seni. } \\
\text { - Alat musik yang digunakan belum } \\
\text { cukup. }\end{array}$ \\
\hline \multirow[t]{3}{*}{2} & \multirow[t]{3}{*}{ Tari } & Pembelajaran & $\begin{array}{l}\text { - Tarian mancanegara perlu praktek } \\
\text { langsung. } \\
\text { - Guru perlu menguasai tarian manca } \\
\text { Negara }\end{array}$ \\
\hline & & Waktu & $\begin{array}{l}\text { Waktu yang ditentukan kurang. } \\
\text { - Waktu ditambahkan pada jam di } \\
\text { luar sekolah. }\end{array}$ \\
\hline & & Sarana Prasarana & $\begin{array}{l}\text { - Perlu ruangan khusus pada saat } \\
\text { praktek. }\end{array}$ \\
\hline \multirow{3}{*}{3} & \multirow{3}{*}{ Rupa } & Pembelajaran & $\begin{array}{l}\text { - } \quad \text { Keterampilan terlalu banyak } \\
\text { Kurangnya materi seni patung } \\
\text { dan seni lukis. }\end{array}$ \\
\hline & & Waktu & - Waktu yang ditentukan kurang \\
\hline & & Sarana prasarana & $\begin{array}{ll}\text { - } & \text { Bahan untuk praktek perlu } \\
\text { disediakan. } \\
\text { - } \\
\text { Perlu ada ruangan khusus untuk } \\
\text { praktek. }\end{array}$ \\
\hline
\end{tabular}


Dari hasil penelitian, pandangan peneliti berdasarkan hasil analisis dengan tujuan penelitian dapat menunjukan bahwa penerapan KTSP khususnya dalam pembelajaran Seni Musik di SMP N 4 Ambon, Maluku masih menjadi masalah. Tetapi guru berusaha mengatasi masalah-masalah ini dengan caranya sendiri dengan menyumbangkan pikirannya melalui solusisolusi yang guru terapkan, juga dengan mempertimbangkan kemampuan anak, alokasi waktu, sarana dan prasarana yang ada. Salah satu contohnya dalam pembelajaran seni musik, untuk mengatasi kendala siswa dalam mengaransir lagu, guru memberikan dasar-dasar teori musik dengan rumusan yang sederhana. Dan untuk kendala waktu, guru memanfaatkan jam ekstrakulikuler untuk memantapkan materi yang diberikan di kelas. sebaliknya untuk pembelajaran seni tari dan seni rupa, guru lebih bnyak memberikan materi praktek dan materi kerajinan atau keterampilan.

Metode pengajaran yang diterapkan guru seni musik, dengan memberikan pengetahuan tentang dasar musik terlebih dahulu, kemudian dengan dilanjutkan dengan materi praktek, seperti yang sudah dijelaskan terlebih dahulu guru menggunakan pendekatan ini dengan pertimbangan pengetahuan dasar anak yang minim. Sebaliknya peneliti melihat belajar musik pada dasarnya adalah pekerjaan mengolah rasa, yang bersumber dari pendengaran. Pendekatan yang perlu dilakukan dalam belajar musik adalah dengan mendengarkan musik dan menikmatinya, dan menirukannya dengan bernyanyi. Setelah itu, pendekatannya dengan menggunakan alat musik, dan memainkanya musik dengan lagu sederhana atau guru juga bisa menggunakan lagu-lagu yang sedang populer saat ini, pengenalan pada teori (notasi) sebaikanya jangan diperkenalkan dulu, karena itu akan membuat siswa binggung, dan akan menimbulkan kejenuhan yang mengakibatkan siswa merasa, belajar musik itu sulit. Setelah anak dapat meminkan dengan baik lagu yang diberikan, barulah diperkenalkan dengan teori dan komposisi yang baik.

Selanjutnya, dapat dilihat metode belajar kebanyakan dilakukan guru dengan cara menonton, misalkan pada pembelajaran seni tari. Sehingga pekerjaan tersebut menjadi pekerjaan yang sangat menjenuhkan baik untuk guru maupun siswa. Selain itu, materi yang diberikan guru sangat sedikit yang bisa diterima oleh siswa. Hal ini bisa dilihat setelah diadakan latihan setelah selesai menyajikan materi pada saat itu juga. Kondisi seperti ini yang perlu diperhatikan oleh guru, dan menuntut guru untuk memikirkan bagaimana cara agar pelajaran yang diberikan dapat diserap dan diterima secara baik oleh siswa. Karena situasi seperti ini akan membuat siswa binggung dan tidak mengerti dengan apa yang diajarkan, sehingga untuk memotivasi siswa untuk belajar sukar dilaksanakan. Oleh sebab itu, perlu dilakukan modifikasi strategi setiap kali pertemuan, agar tidak membosankan. Salah satu strategi yang dapat dilakukan guru yaitu membuat siswa merasa rileks di kelas, dengan memutarkan musik kemudian siswa di ajak untuk aktif atau menciptakan gerakan, suara sendiri, sehingga cara ini dapat memotivasi siswa untuk kreatif.

Metode pengajaran pada dasarnya ditentukan oleh sejumlah faktor. Gellrich \& Sundin (1993) berpendapat belajar secara kreatif (belajar dengan menemukan) mulai digantikan belajar dengan cara reproduktif. Keputusan itu hanya kepentingan dalam penyusunan kurikulum yang akhirnya menjadikan musik sebagai sebuah cabang seni yang khusus. Peter Maxwell Davies, George Self, Brian Dennis dan Murray Schafer yaitu para komponis juga seorang guru musik, karya mereka tidak hanya meredefinisikan peran musik dalam pendidikan tetapi juga sebagai stimulus yang kuat bagi sebuah metode pengajaran musik yang revolusioner, yaitu mengajar dari apa yang ada dan dari eksplorasi imajinatif para siswa (Djohan, 2009). Faktor-faktor terpenting dalam efektivitas kurikulum khususnya dalam pendidikan seni musik salah satunya adalah Guru. Guru berperan penting dalam menyusun dan merumuskan bahan pelajaran yang sesuai dengan kebutuhan minat dan perkembangan anak. Implementasi kurikulum hampir seluruhnya bergantung pada kreativitas, kecakapan, kesungguhan dan ketekunan guru. Hal ini sejalan dengan pendapat caswell, yang mengatakan dalam efektivitas kurikulum menekankan pada partisipasi guru untuk menentukan struktur, pembelajaran dan dampai pada merumuskan kurikulum.

Hal ini dapat dilihat dari usaha Guru Seni pada SMP N 4 Ambon dalam memilih dan mencoba menciptakan situasi-situasi belajar yang memacu kreatifitas anak, dan mencoba memberikan solusi guna dalam memecahkan masalah dalam proses pembelajaran yang sesuai dengan kemampuan siswa, sehingga dalam proses belajar mengajar guru banyak mengaktifkan siswa. Sehingga penelitian ini menunjukan bahwa dalam Efektivitas KTSP pada Pembelajaran Seni Musik harus terus dilakukan, dengan mempertimbangkan perkembangan anak, sarana-prasarana sekolah, serta waktu. Tujuannya agar Efektivitas KTSP pada pembelajaran seni musik ini dapat mudah diimplementasikan guru, dan dapat memberikan panduan yang komprehensif sehingga dapat berguna sebagai media dan sumber belajar, serta dapat mentimulasi dan memotifasi guru untuk mengolah dan mengembangkan ide-ide kreatifitasnya dalam pembelajaran

\section{KESIMPULAN}

Efektifitas Kurikulum Tingkat Satuan Pendidikan dalam pelajaran Seni Musik di SMP 4 Ambon sangat diperlukan, oleh sebab itu dalam implementasinya diharapkan dukungan dan kerjasama dari pemerintah, sekolah, guru dan siswa, demi peningkatan mutu pendidikan di Indonesia pada umumnya dan lebih khusus di SMP N 4 Ambon, Maluku. Setelah melakukan penelitian maka kesimpulannya sebagai berikut : 
1. Pelaksanaan KTSP pada SMP N 4 Ambon sudah berjalan dengan peraturan yang berlaku.

2. Guru berupaya mengatasi kesulitan siswa dengan turut menyumbangkan pemikirannya melalui solusi-solusi yang sudah diterapkannya. Misalnya, dalam mengaransir lagu mancanegara dengan menggunakan aransemen sederhana terlebih dahulu dan untuk mengatasi keterbatasan waktu, guru memanafaatkan kegiatan ekstrakulikuler.

\section{DAFTAR PUSTAKA}

Ahmadi, H. A., dan Uhbiyati. 1991. Ilmu Pendidikan. Jakarta: Rineka Cipta

Badan Standar Nasional Pendidikan. 2006. Panduan Penyusunan Kurikulum Kurikulum Tingkat Satuan Pendidika Jenjang Pendidikan Dasar dan Menengah. Jakarat: BSNP Depdiknas

Bastomi, Suwaji. 1993. Proses Apresiasi, Kreasi, dan Belajar. Semarang: IKIP Semarang Press

Collins, Kelvin. 1988. The art framwork. Melbourne: Ministry of education

Depdikbud. 1989. Sistem Pendidikan Nasional (UU RI NO. 2 tahun 1989).

Depdiknas. 2004. Kurikulum 2004: Kerangka Dasar. Jakarta : Depdiknas

Djohan. 2009. Psikologi musik. Yogyakarta: Best Publisher

Hamalik, O.2001. Proses Belajar Mengajar. Bandung: Bumi Aksara

Mulyasa, E. 2006. Kurikulum Yang Disempurnakan : Pengembangan Standar dan Kompetensi Dasar. Bandung : Remaja Rosdakarya

Nasution, S. 1980. Azaz-azaz Kurikulum. Bandung: Jemmars.
Olivia, P. E. 1992. Developing the Curriculum. New York: Harper Collins Publisher.

Peraturan Menteri Pendidikan Nasional Nomor 22 Tahun 2006 tentag Standar Isi

Peraturan Menteri Pendidikan Nasional Nomor 23 Tahun 2006 Standar Komptensi Kelulusan

Peraturan Pemerintah Nomor 19 Tahun 2005 tentang Standar Nasional Pendidikan

Peraturan Pemerintah Nomor 25 tahun 2000 tentang Pertimbangan Keuangan

Antara Pemerintah Pusat dan Daerah

Bonoe. Pono, 2002. Kamus Umum Musik. Yogyakarta: Kanisius

Roestiyah N. K. 2008. Strategi Belajar Mengajar. Cetakan ke -7 : Jakarta Rineka Cipta.

Rohidi, Tjetjep. 2000. Kesenian Dalam Pendekatan Kebudayaan. Bandung:STISI, Bandung press

Singgih. D. G. 2008. Dasar dan Teori Perkembangan Anak. Jakarta: PT BPK Gunung Mulia.

Sukmadinata, N. S. 2009. Pengembangan Kurikulum: Teori dan Praktik. Cetakan ke - 11. Bandung: Remaja Rosda Karya.

Sumaryo L.E. 1958. Estetika Musik, Yogyakarta: SMIND

Surahmad, W. 1997. Pembinaan dan Pengembangan Kurikulum.

Jakarta: Proyek Pengadaan Buku Sekolah Pendidikan Guru.

Undang - undang No 22 tahun 1999 tentang Pemerintahan Daerah

Walters D.L (1989). Reading in Music Learning Theory. Chicago: G.I.A publicaton 